\title{
Notes
}

\section{Land Use Regulation, the Federal Courts, and the Abstention Doctrine}

Despite frequent invitations to impose constitutional restraints on local government regulation of private land use, ${ }^{1}$ the federal judiciary has consistently declined "to sit as a zoning board of appeals."2 Recent decisions expanding the scope of private actions under 42 U.S.C. $\S 1983,{ }^{3}$ however, have encouraged more frequent challenges to local land use regulations ${ }^{4}$ in federal court. ${ }^{5}$ Given the traditional reluctance of federal courts to decide land use cases, the enhanced attractiveness of the federal forum calls for more careful examination of abstention ${ }^{6}$ as a device for limiting federal land use litigation.

Although abstention to allow state courts to decide a case within federal jurisdiction is normally the exception, ${ }^{7}$ several courts have suggested recently that abstention is especially appropriate in land use cases. ${ }^{8}$ This Note argues that a federal judicial policy of abstaining from

1. For example, several recent Supreme Court cases challenged local land use regulations that effectively prevented low-income persons from residing in a community. See Village of Arlington Heights v. Metropolitan Hous. Dev. Corp., 429 U.S. 252 (1977); Warth v. Seldin, 422 U.S. 490 (1975).

2. Village of Belle Terre v. Boraas, 416 U.S. 1, 13 (1973) (Marshall, J., dissenting); accord, Steel Hill Dev., Inc. v. Town of Sanbornton, 469 F.2d 956, 960 (Ist Cir. 1972); see pp. 1135-36 infra (discussing judicial reluctance to decide land use cases).

3. 42 U.S.C. $\$ 1983$ (1976) (person who, under color of state law, subjects citizen "to the deprivation of any rights, privileges, or immunities secured by the Constitution and laws," liable to party injured); see p. 1138 infra (listing typical $\$ 1983$ land use actions).

4. This Note uses the term "land use regulations" to refer to zoning ordinances, subdivision controls, growth-management programs, and similar legal devices adopted by states and municipalities to control uses of private land.

5. Monell v. Department of Social Services, 436 U.S. 658 (1978) (municipality is considered a "person" for $\$ 1983$ purposes); Lynch v. Household Fin. Corp., 405 U.S. 538 (1972) (\$ 1983 supports action to protect property rights); see pp. 1136-39 infra (discussing impact of Monell and Lynch).

6. Abstention doctrine refers to various circumstances in which a federal court may decline to proceed although it has constitutional and statutory jurisdiction. See pp. 1140-41 infra (outlining three branches of abstention doctrine).

7. Colorado River Water Conservation Dist. v. United States, 424 U.S. 800, 813 (1976); County of Allegheny v. Frank Mashuda Co., 360 U.S. 185, 188.89 (1959).

8. E.g., Santa Fe Land Improvement Co. v. City of Chula Vista, 596 F.2d 838 (9th Cir. 1979); Kent Island Joint Venture v. Smith, 452 F. Supp. 455, 463 (D. Md. 1978); Stallworth v. Gity of Monroeville, 426 F. Supp. 236 (S.D. Ala. 1976). The increasing number of 
deciding most land use disputes is necessary to promote the values of federalism and to achieve efficient resolution of land use disputes. The Note contends, however, that the importance of preserving a federal forum for the protection of constitutional rights militates against a categorical rule of abstention in land use cases. The Note therefore proposes a general policy of abstention in land use cases; application of the policy in particular cases, however, should depend upon three considerations: whether the asserted constitutional right is fundamental in nature, whether the state is involved in local land use regulation, and whether the regulations single out individual landowners for unfair treatment.

\section{Land Use Cases and the Federal Courts}

Conflict between the responsibility of federal courts for enforcing constitutional norms, and their intuitive sense that land use cases belong in state courts, is apparent in the federal judiciary's past treatment of land use cases. In response to the recent increase in federal land use litigation, courts have frequently abstained as a means of relegating land use cases to state courts.

\section{A. Conflicting Trends}

\section{Federal Reluctance to Decide Land Use Cases}

Since it decided Village of Euclid v. Ambler Realty Co. ${ }^{9}$ in 1926, the Supreme Court has heard few land use cases. ${ }^{10}$ Although the Court reentered the land use field in the $1970 \mathrm{~s},{ }^{11}$ its disposition of the recent

land use cases that discuss abstention demonstrates the growing importance of this issue. Less than 10 land use cases decided prior to 1970 discuss abstention, e.g., McLarty v. Borough of Ramsey, 270 F.2d 232 (3d Cir. 1959); Lerner v. Town of Islip, 272 F. Supp. 664 (E.D.N.Y. 1967); at least 50 cases decided since 1970 discuss the issue. See Strom, Local Zoning and the Federal Courts, 1 Zoning \& PLAN. L. ReP. 73, $77-78$ (1978) (noting more frequent abstentions in land use cases).

9. 272 U.S. 365 (1926) (upholding zoning ordinance challenged as violative of equal protection and due process guarantees).

10. The Court heard four land use cases in the two years following Euclid. Seattle Title Trust Co. v. Roberge, 278 U.S. 116 (1928); Nectow v. City of Cambridge, 277 U.S. 183 (1928); Gorieb v. Fox, 274 U.S. 603 (1927); Zahn v. Board of Pub. Works, 274 U.S. 325 (1927). Between 1930 and 1970 the Court virtually abandoned the land use field, hearing only three cases: Goldblatt v. Town of Hempstead, 369 U.S. 590 (1962); Hurd v. Hodge, 334 U.S. 24 (1948); Shelley v. Kraemer, 334 U.S. 1 (1948). See 5 N. Williams, AMERICAN Planning Law 557.58 (1975).

11. The Court heard eight land use cases during that decade: Lake Country Estates, Inc. v. Tahoe Regional Planning Agency, 440 U.S. 391 (1979); Penn Cent. Transp. Co. v. New York City, 438 U.S. 104 (1978); Moore v. City of East Cleveland, 431 U.S. 494 (1977); Village of Arlington Heights v. Metropolitan Hous. Dev. Corp., 429 U.S. 252 (1977); 
cases has tended to discourage federal land use litigation..$^{12}$ The volume of land use litigation in the lower federal courts has increased in recent years, but a variety of procedural ${ }^{13}$ and substantive ${ }^{14}$ devices, including abstention, have been invoked to discourage land use litigants from entering federal court.

\section{Expansion of Land Use Litigants' Federal Rights}

Despite this pattern of hostility toward land use claims, two recent Supreme Court decisions have enhanced the attractiveness of the federal forum to land use litigants. In Lynch v. Household Finance Corp., ${ }^{15}$ the Court eliminated the jurisdictional amount requirement as a poten-

Young v. American Mini Theatres, Inc., 427 U.S. 50 (1976); Warth v. Seldin, 422 U.S. 490 (1975); Village of Belle Terre v. Boraas, 416 U.S. 1 (1974); James v. Valtierra, 402 U.S. 137 (1971); see N. Williams, supra note 10, at 557-58 (1975) \& 53 (Supp. 1978). Another land use case is currently before the Court. Agins v. City of Tiburon, 24 Cal. 3d 266, 598 P.2d 25, 157 Cal. Rptr. 372 (1979), cert. granted, 100 S. Ct. 658 (1980).

12. With the exception of Moore v. City of East Cleveland, 431 U.S. 494 (1977), the Court has not awarded plaintiffs relief in any land use cases decided since 1970. The Court's recent activity in the land use field therefore has not established any clear constitutional restraints on public regulation of private land use.

Moreover, the Court has erected new obstacles to adjudication of certain land use disputes in federal court. In Village of Arlington Heights v. Metropolitan Hous. Dev. Corp., 429 U.S. 252 (1977), the Court held that local land use restrictions precluding low-income minority groups from residing in the community did not, absent proof of intentional discrimination, violate the equal protection clause. Together with Warth v. Seldin, 422 U.S. 490 (1975) (nonresident challengers of town's exclusionary zoning lacked standing), Arlington Heights has forced opponents of exclusionary zoning to concentrate their efforts in state courts. See, e.g., Oakwood at Madison, Inc. v. Township of Madison, 72 N.J. 481, 371 A.2d 1192 (1977); Berenson v. Town of New Castle, 67 A.D.2d 506, 415 N.Y.S.2d 669 (1979). See generally Sager, Insular Majorities Unabated: Warth v. Seldin and City of Eastlake v. Forest City Enterprises, Inc., 91 Harv. L. REv. 1373, 1375 (1978) (discussing Supreme Court hostility to exclusionary zoning claims).

13. For example, the standing doctrine has been invoked to bar challenges to municipal land use regulations that allegedly harm nonresidents. See, e.g., Construction Indus. Ass'n v. City of Petaluma, 522 F.2d 897 (9th Cir. 1975), cert. denied, 424 U.S. 934 (1976); United States Gen., Inc. v. City of Joliet, 432 F. Supp. 346 (N.D. Ill. 1977). In addition, the jurisdictional requirements of 28 U.S.C. $\$ 1331$ (1976), that the amount in controversy exceed $\$ 10,000$, has sometimes been a barrier to federal land use litigants. See, e.g., Ybarra v. City of Los Altos Hills, 503 F.2d 250 ( 9 th Cir. 1974); Eisen v. Eastman, 421 F.2d 560, 566 (2d Cir. 1969).

14. In Village of Euclid v. Ambler Realty Co., 272 U.S. 365 (1926), the Supreme Court established a permissive standard for substantive due process review: "it must be said before the ordinance can be declared unconstitutional, that [its] provisions are clearly arbitrary and unreasonable, having no substantial relation to the public health, safety, morals, or general welfare." $I d$. at 395 . Lower courts have invoked that standard to deny relief to land use litigants. See, e.g., Rogin v. Bensalem Township, 48 U.S.L.W. 2593, 2594 (3d Gir. Feb. 21, 1980) ("absent defects in the process of enacting the legislation, or of manifest irrationality in the results flowing from that process, courts will uphold state and local land use regulations against challenges based on federal constitutional grounds"); Confederacion de la Raza Unida v. City of Morgan Hill, 324 F. Supp. 895, 897 (N.D. CaI. 1971) ("courts should interfere with the judgment of the local authorities only in the most extreme cases, and under the most extreme circumstances").

15. 405 U.S. 538 (1972). 
tial barrier to "takings" claims in federal courts, ${ }^{16}$ by holding that section 1983 could be used to vindicate property rights. ${ }^{17}$

Monell v. Department of Social Services ${ }^{18}$ was even more significant. In that decision, the Supreme Court expanded the scope of municipal liability for constitutional violations. Prior to Monell, federal courts had generally granted only injunctive or declaratory relief against unconstitutional municipal regulations. ${ }^{19}$ Though damages could in theory be recovered from municipal officials for their unconstitutional acts, ${ }^{20}$ immunity doctrine ${ }^{21}$ and other practical considerations ${ }^{22}$ often barred recovery. In Monell, however, the Court held that municipalities are persons for purposes of section 1983..3 The Court therefore established for the first time that damages could be recovered directly from a municipality for constitutional violations in suits brought under section 1983.24

16. 28 U.S.C. $\$ 1331$ (1976) (\$10,000 jurisdictional amount).

17. 405 U.S. at 543.

18. 436 U.S. 658 (1978).

19. See, e.g., Village of Euclid v. Ambler Realty Co., 272 U.S. 365 (1926); Mosher v. City of Phoenix, 287 U.S. 29 (1932); Sixth Camden Corp. v. Evesham Township, 420 F. Supp. 709, 727 (D.N.J. 1976) (citing cases).

20. Monroe v. Pape, 365 U.S. 167, 172 (1961).

21. A number of lower federal courts have held that local legislators, like state legislators, Tenney v. Brandhove, 341 U.S. 367 (195I), and federal legislators, United States v."Johnson, 383 U.S. 169 (1966), are immune from suit for their legislative acts. See, e.g., Fralin \& Waldron, Inc. v. County of Henrico, 474 F. Supp. 1315, 1320 (E.D. Va. 1979); Shellburne, Inc. v. New Castle County, 293 F. Supp. 237, 241-44 (D. Del. 1968). The Supreme Court has not decided this issue. Lake Country Estates, Inc. v. Tahoe Regional Planning Agency, 440 U.S. 391, 401 n.26 (1979). An executive official is immune from liability so long as he acted within the scope of his legitimately defined discretionary authority. Scheuer v. Rhodes, 416 U.S. 232, $247-48$ (1974); Fralin \& Waldron, Inc. v. County of Henrico, 474 F. Supp. 1315, 1320-21 (E.D. Va. 1979).

22. A municipal official might lack the means to pay a judgment, a jury might be reluctant to assess damages against an official who was performing his job, or the plaintiff might not be able to establish which of several officials was responsible for the constitutional injury. See Note, Damage Remedies Against Municipalities for Constitutional Violations, 89 HARv. L. REv. 922, 923 (1976).

23. 436 U.S. at 663; see note 3 supra (quoting 42 U.S.C. $\$ 1983$ (1976)). Monell overruled in part Monroe v. Pape, 365 U.S. 167, 187.92 (1961) (municipalities are not "persons" subject to suit under $\S 1983$ ) and City of Kenosha v. Brown, 412 U.S. 507, 511-14 (1973) ( $\$ 1983$ does not support action for injunctive relief against city).

24. The Monell Court held that the legislative history of section 1983 demonstrated Congress' intent to impose liability on municipalities only for an unconstitutional "official custom" or "policy." 436 U.S. at 694 . The Court expressly precluded municipal liability under the doctrine of respondeat superior. $I d$. Given that land use regulations are generally adopted by ordinance, whether the constitutional wrong resulted from official municipal policy will rarely be an issue in land use cases. The Court decided only that municipalities cannot be afforded an absolute immunity, reserving the question whether municipalities are entitled to some form of official immunity. Id. at 701. This issue was resolved in Owen v. City of Independence, 48 U.S.L.W. 4389 (U.S. April 16, 1980), in which the Court held that municipalities have no immunity from liability in section 1983 actions. See generally Schnapper, Civil Rights Litigation After Monell, 79 CoLum. L. REv. 213, 245.47 (1979) (reasons supporting good-faith immunity for executive officials do not support good-faith immunity for municipalities). 
As a result of Monell, federal remedies appear to be superior to available state relief in land use cases. ${ }^{25} \mathrm{~A}$ municipality may now be liable in damages ${ }^{26}$ under federal law for a taking in violation of the Fifth Amendment, ${ }^{27}$ a deprivation of due process ${ }^{28}$ or equal protection rights, ${ }^{29}$ or an abridgement of the First Amendment. ${ }^{30}$ By contrast,

25. Prior to Monell, some lower federal courts, relying on Bivens v. Six Unknown Named Agents, 403 U.S. 388 (1971), had held that a direct cause of action for damages based on the Fourteenth Amendment was available to challenge unconstitutional land use regulations. See, e.g., Barbaccia v. County of Santa Clara, 45I F. Supp. 260, 265-66 (N.D. Cal. 1978); Sixth Camden Corp. v. Evesham Township, 420 F. Supp. 709, 715-17 (D.N.J. 1976). The Supreme Court has reserved the question of the availability of a direct cause of action based on the Fourteenth Amendment. Lake Country Estates, Inc. v. Tahoe Regional Planning Agency, 440 U.S. 391, 398 (1979); Mt. Healthy City School Dist. Bd. of Educ. v. Doyle, 429 U.S. 274,278 (1976).

26. While the extent of municipal liability under section 1983 in the land use context remains to be defined precisely, it seems clear that Monell supports some form of damage relief against unconstitutional regulations. In Lake Country Estates, Inc. v. Tahoe Regional Planning Agency, 440 U.S. 391 (1979), the Court suggested that damages might be an appropriate remedy if unconstitutional regulations had been adopted by the agency. Id. at 405 n.29. Lower courts have read Monell as authorizing damage relief in land use cases. See, e.g., Fralin \& Waldron, Inc. v. County of Henrico, 474 F. Supp. 1315 (E.D. Va. 1979); Gipson v. Township of Bass River, 82 F.R.D. 122 (D.N.J. 1979) (dictum). Nevertheless, a declaration of invalidity may still be sufficient relief in certain instances. See Agins v. City of Tiburon, 24 Cal. 3d 266, 598 P.2d 25, 157 Cal. Rptr. 372 (1979), cert. granled, 100 S. Ct. 658 (1980) (no inverse condemnation claim in zoning challenges); Note, Inverse Condemnation: Its Availability in Challenging the Validity of a Zoning Ordinance, 26 STAN. L. REv. 1439 (1974) (damages should not be awarded against municipalities when zoning held unconstitutional).

27. Even before Bivens v. Six Unknown Named Agents, 403 U.S. 388 (1971), lower federal courts had entertained damages actions for limited types of takings-for example, actual physical invasions of land, e.g., Lowe v. Manhattan Beach, 222 F.2d 258 (9th Cir. 1955), or abuse of municipal eminent domain powers, e.g., Foster v. City of Detroit, 405 F.2d 138 (6th Cir. 1968). See Note, supra note 22, at 950 n.145. Subsequent federal cases, relying on Bivens, awarded damages for temporary and permanent takings resulting from unconstitutional land use regulations. See, e.g., Gordon v. City of Warren, 579 F.2d 386 (6th Cir. 1978); Dahl v. City of Palo Alto, 372 F. Supp. 647 (N.D. Cal. 1974). But see Brault v. Town of Milton, 527 F.2d 730, 734-35 (2d Cir. 1975) (en banc) (municipality immune in Bivens-type action).

These precedents will be applicable in future section 1983 land use actions because courts generally apply law developed in section 1983 litigation "to fill the doctrinal interstices of a Bivens-type action." Sixth Camden Corp. v. Evesham Township, 420 F. Supp. 709, 717 (D.N.J. 1976); accord, Jacobson v. Tahoe Regional Planning Agency, 558 F.2d 928, 942 (9th Cir. 1977), rev'd on other grounds sub nom. Lake Country Estates, Inc. v. Tahoe Regional Planning Agency, 440 U.S. 391 (1979).

28. See, e.g., Citizens Ass'n of Georgetown, Inc. v. Zoning Comm'n of the Dist. of Columbia, 477 F.2d 402 (D.C. Cir. 1973); Metropolitan Hous. Dev. Corp. v. Village of Arlington Heights, 469 F. Supp. 836, 858-62 (N.D. Ill. 1979). See generally Developments in the Law-Zoning, 91 HARv. L. Rev. 1427, 1504-28 (1978) [hereinafter cited as Developments-Zoning] (discussing due process challenges to zoning regulations).

29. See, e.g., Fralin \& Waldron, Inc. v. County of Henrico, 474 F. Supp. 1315 (E.D. Va. 1979); Sixth Camden Corp. v. Evesham Township, 420 F. Supp. 709 (D.N.J. 1976).

30. Some localities have recently used land use regulation to control certain types of expression. See Young v. American Mini Theatres, Inc., 427 U.S. 50 (1976); DevelopmentsZoning, supra note 28, at 1550-68 (discussing conflicts between First Amendment and zoning objectives). 
governmental immunity doctrine under state law generally protects municipalities from suit to recover economic losses caused by enforcement of unconstitutional regulations. ${ }^{31}$ Moreover, most states have held that damages are not a proper remedy when land use regulations effect a taking. ${ }^{32}$

Because section 1983 claims may be presented in either state or federal court, ${ }^{33}$ the prospect of broader relief under federal law need not necessarily lead to an influx of land use cases into federal court. Yet the commonly held beliefs that federal courts are more vigilant protectors of federal rights than are state courts, ${ }^{34}$ and that state courts are more open to political influence, ${ }^{35}$ will probably lead most section 1983 land use litigants to bring their actions in federal court.

The conflict between the historical preference of federal courts for leaving land use decisions to state courts, and the recent expansion of land use litigants' substantive federal claims, ${ }^{36}$ requires some resolu-

31. See, e.g., HFH, Ltd. v. Superior Court, 15 Cal. 3d 508, 542 P.2d 237, 125 Cal. Rptr. 365 (1975); Veling v. Borough of Ramsey, 94 N.J. Super. 459, 228 A.2d 873 (1967); 18 E. McQunilin, The Law of Municipal Corporations $\$ 53.22 \mathrm{c}$ (3d ed. 1977). Although the scope of municipal tort liability under state law has expanded in recent years, see Note, Mrunicipal Tort Liability: A Legislative Solution Balancing the Needs of Cities and Plaintiffs, 16 URB. L. ANN. 305 (1979), most states continue to recognize immunity for governmental actions that are legislative or discretionary in nature, such as enactment of land use ordinances, see E. McQulluin, supra, at \$53.04a; Note, supra, at 314 .

32. The majority of state courts have held that damages are not recoverable when a challenge to land use regulations is successful. See, e.g., Agins v. City of Tiburon, 24 Cal. 3d 266, 598 P.2d 25, 157 Cal. Rptr. 372 (1979), cert. granted, 100 S. Ct. 658 (1980); Gold Run, Ltd. v. Board of County Comm'rs, 38 Colo. App. 44, 554 P.2d 317 (1976); Fifth Ave. Corp. v. Washington County, 282 Or. 591, 581 P.2d 50 (1978) (en banc); cf. Fred F. French Investing Co. v. City of New York, 39 N.Y.2d 587, 350 N.E.2d 381, 385 N.Y.S.2d 5, cert. denied and appeal dismissed, 429 U.S. 990 (1976) (no inverse condemnation action; damages may be recoverable). Contra City of Miami v. Romer, 73 So. 2d 285 (Fla. 1954); City of Austin v. Teague, 570 S.W.2d 389 (Tex. 1978).

33. Testa v. Katt, 330 U.S. 386 (1947); see P. Bator, P. Mishkin, D. Shapiro, \& H. Wrchsler, Hart and Wechsler's The Federal Courts and the Federal System 431-38 (2d ed. 1973) [hereinafter cited as HART \& WECHSLER].

34. See N. Dorsen, P. Bender, \& B. Neuborne, Political and Givil Rights in the United States 1293-94 (4th ed. 1976); Neuborne, The Myth of Parity, 90 Harv. L. Rev. 1105,1115 (1977). The Supreme Court, however, has consistently decided forum-allocation decisions on the assumption that state and federal courts are equally effective protectors of constitutional rights. See, e.g., Moore v. Sims, 442 U.S. 415, 430 (1979); Stone v. Powell, 428 U.S. 465,493 \& $n .35$ (1976). That the Court's assumption is not widely accepted by litigants is indicated by the fact that the 17,500 section 1983 actions filed in federal court during 1976 represented a $300 \%$ increase over the number filed in 1970 . See HarT \& WECHSLER, supra note 33, at 149 (Supp. 1977). The total number of state court section 1983 actions ever decided is less than 1,000 .

35. See Mitchum v. Foster, 407 U.S. 225, 240 (1972) (concluding that $\$ 1983$ was enacted because state courts were being used to harass minorities); Neuborne, supra note 34, at 1127-28 (unlike life-term federal judges, state judges generally elected for fixed term and therefore less insulated from majoritarian pressures).

36. City of Lafayette v. Louisiana Power \& Light Co., 435 U.S. 389 (1978), decided the same term as Monell, also will expand the volume of land use litigation in federal court. The City of Lafayette Court held that municipalities are "persons" within the meaning 
tion. Lower federal courts have begun to experiment with abstention doctrine as one device for accommodating the competing trends.

\section{B. Abstention and Land Use Litigation}

\section{Abstention Doctrine and Federalism}

Federal courts repeatedly assert a general obligation to hear constitutional claims. ${ }^{37}$ That obligation, however, is subject to a variety of prudential limitations, ${ }^{38}$ among which are the three branches of the abstention doctrine..$^{30}$

The first branch of abstention doctrine derives from Railroad Commission of Texas $v$. Pullman. ${ }^{40}$ Under the Pullman doctrine, a federal court should abstain from deciding a case involving a sensitive constitutional issue that might be eliminated, or at least modified, by state court resolution of an uncertain state law question. ${ }^{41} \mathrm{~A}$ second branch

of the Sherman and Clayton Antitrust Acts and therefore can be held directly liable for antitrust violations. Several lower courts have held that municipal land use regulations can constitute antitrust violations. See, e.g., Mason City Center Assocs. v. City of Mason City, 468 F. Supp. 737 (N.D. Iowa 1979); Nelson v. Utah County, [1978-1] Trade, Cases (CCH) $\$ 62,128$ (D. Utah 1977) (relying on court of appeals ruling in City of Lafayette). Although 15 U.S.C. $\$ 15$ (1976) vests exclusive jurisdiction in the federal courts to hear federal antitrust claims, abstention is not precluded. See Mach-Tronics, Inc. v. Zirpoli, 316 F.2d 820, 824-28 (9th Cir. 1963); Schenley Indus., Inc. v. New Jersey Wine \&: Spirits Wholesalers Ass'n, 272 F. Supp. 872, 882-83 (D.N.J. 1967).

37. See England v. Louisiana State Bd. of Medical Examiners, 375 U.S. 411,415 (1964) (quoting Wilcox v. Consolidated Gas Co., 212 U.S. 19, 40 (1909) (" "When a federal court is properly appealed to in a case over which it has by law jurisdiction, it is its duty to take such jurisdiction." ")); McClellan v. Carland, 217 U.S. 268, 281 (1910) (same); Cohens v. Virginia, 19 U.S. (6 Wheat.) 264, 404 (1821) (same). This "rule" is subject to numerous qualifications. See note 38 infra; cf. Note, Power to Stay Federal Proceedings Pending Termination of Concurrent State Litigation, 59 YALE L.J. 978, 980-81 (1950) (referring to "supposed ... 'absolute' right" to benefit of federal jurisdiction as "originating in in. auspicious dicta").

38. For example, prudential considerations apply in standing doctrine, HART \& WECHSLER, supra note 33 , at 150.85 , political question doctrine, id. at 214-41, abstention doctrine, $i d$. at 985-1050, and rules governing conflicts of jurisdiction between state and federal courts, id. at 1230-59; see A. Bicker, The Least Dangerous Branch 113-27 (1962) (discussing Supreme Court practice of withholding power of judicial review).

39. See Field, Abstention in Constitutional Cases: The Scope of the Pullman Abstention Doctrine, 122 U. PA. L. REv. 1071 (1974).

40. 312 U.S. 496 (1941).

41. In addition to requiring an uncertain state law question upon which a sensitive constitutional issue depends, Pullman abstention requires an adequate state remedy be available. Id. at 501 . When Pullman abstention is ordered, the plaintiff may either submit his federal claims for state court resolution or reserve them for subsequent federal court determination; accordingly, the federal court generally retains jurisdiction over the case. In any event, the plaintiff is required to inform the state court of his constitutional claims in order to permit that court to consider them in construing the state law. See England v. Louisiana State Bd. of Medical Examiners, 375 U.S. 411, 419-21 (1964); Field, supra note 39 , at 1079 . 
of the abstention doctrine, derived from Burford $v$. Sun Oil Co., ${ }^{42}$ is invoked when federal judicial action would be "disruptive of state efforts to establish a coherent policy with respect to a matter of substantial public concern." 43 Finally, abstention is appropriate under the rule of Younger v. Harris ${ }^{44}$ when, "absent bad faith, harassment, or a patently invalid state statute, federal jurisdiction has been invoked for the purpose of restraining state criminal proceedings" 45 or state "civil proceedings in which important state interests are involved." 46

The three branches of the abstention doctrine rest in part on the more general concept of federalism, the notion that "attributes of sovereignty attaching to every state government" impose limitations on federal power, ${ }^{47}$ including the exercise of jurisdiction by the federal courts. ${ }^{48}$ The instrumental values of federal deference to state and local decisionmaking include assuring greater public access to government, facilitating development of policies responsive to local conditions, and allowing each state to serve as a "laboratory" of social policy for the benefit of the nation. ${ }^{49}$

Only a limited set of federal impositions on the states is prohibited absolutely by the federalism doctrine. ${ }^{50}$ Nevertheless, federalism is a

42. 319 U.S. 315 (1943). Unlike Pullman abstention, Burford abstention is not predicated on the presence of either uncertain state law or a federal constitutional issue. Burford abstention also differs from the Pullman branch in that it results in dismissal of the case; the plaintiff must therefore submit all of his claims to the state court, even if they rest on federal law. Alabama Pub. Serv. Comm'n v. Southern Ry., 341 U.S. 341, 350 (1951); see Field, supra note 39, at 1153.

43. Colorado River Water Conservation Dist. v. United States, 424 U.S. 800, 814 (1976).

44. 401 U.S. 37 (1971).

45. Colorado River Water Conservation Dist. v. United States, 424 U.S. 800, 816 (1976).

46. Moore v. Sims, 442 U.S. 415,423 (1979). The Younger branch of abstention doctrine has undergone considerable evolution in recent years. Originally confined to state criminal proceedings, Younger gradually has been expanded by the Court to include some civil cases. See, e.g., id. at 419 (state suit seeking emergency custody to protect battered children); Trainor v. Hernandez, 431 U.S. 434, 444 (1977) (attachment by state in proceedings to recover funds fraudulently received under public assistance program); Huffman v. Pursue, Ltd., 420 U.S. 592, 604 (1975) (civil nuisance action commenced by state "in aid of and closely related to criminal statutes").

47. National League of Cities v. Usery, 426 U.S. 833, 845 (1976).

48. Younger v. Harris, 401 U.S. 37, 43.44 (1971).

49. See Developments in the Law-Section $19 S 3$ and Federalism, 90 HARv. L. Rev. 1133, 1180 (1977) [hereinafter cited as Developments-Federalism]; cf. New State Ice Co. v. Liebmann, 285 U.S. 262, 311 (1932) (Brandeis, J., dissenting) (stressing importance of states as social and economic laboratories).

50. Although National League of Cities v. Usery, 426 U.S. 833 (1976), refuted the notion that the Tenth Amendment is a constitutional dead letter, id. at 842-43, the exact scope of proscribed congressional impositions on the states is uncertain. At its core, the Court's constitutional federalism doctrine protects the existence and political accountability of the states as independent units of government. See id. at 848 ("[T]he federal requirement directly supplants the considered policy choices of the States' elected officials and administrators as to how they wish to structure pay scales in state employment'); Coyle v. 
potent prudential consideration that courts may invoke in determining how and when to assert their jurisdiction. ${ }^{51}$

\section{Abstention and Land Use: The Rule and Not the Exception?}

Despite frequent judicial declarations that "[a]bstention from the exercise of federal jurisdiction is the exception, not the rule," "s2 recent federal cases suggest that abstention in land use cases may in fact have become the rule. ${ }^{53}$ Not surprisingly, reliance on abstention to avoid adjudication of land use disputes has been most common in those states in which innovative land use programs have spawned extensive litigation. ${ }^{54}$

The manner in which courts have manipulated traditional doctrine in order to justify abstention illustrates the judicial predisposition to abstain in land use cases. Some courts have relied on expansive con-

Oklahoma, 221 U.S. 559, 565 (1911) ("The power to locate its own scat of government and to determine when and how it shall be changed . . . are essentially and peculiarly state powers"); District of Columbia v. Train, 521 F.2d 971, 994 (D.C. Cir. 1975), remanded and vacated on other grounds sub nom. Environmental Protection Agency v. Brown, 431 U.S. 99 (1977) ("A federal regulation which compels the states to enforce federal regulatory programs clearly 'impairs the States' integrity' and 'their ability to function in a federal system':").

The Eleventh Amendment is a narrow, but strict, limitation on federal judicial power vis-i-vis the states. See, e.g., Edelman v. Jordan, 415 U.S. 651 (1974) (Eleventh Amendment bars award of retroactive benefits due plaintiffs under state public assistance program).

51. See Trainor v. Hernandez, 431 U.S. 434, 440 (1977) (federal court should inquire into its "proper role" in litigation when there is concurrent state proceeding); Mitchum v. Foster, 407 U.S. 225, 243 (1972) (although $\S 1983$ is exception to the anti-injunction statute, federal court still restrained by "principles of equity, comity, and federalism"); Younger v. Harris, 401 U.S. 37, 44 (1971) (federalism does not absolutely protect "States' Rights" from interference, but refers to "a system in which there is sensitivity to the legitimate interests of both State and National Governments"); Louisiana Power \& Light Co. v. City of Thibodaux, 360 U.S. 25, 29 (1959) (abstention is justified by "regard for the respective competence of the state and federal court systems and for the maintenance of harmonious federal-state relations in a matter close to the political interests of a State"). Thus, though constitutionally based, federalism-like the three types of abstentiongenerally represents a discretionary, rather than an obligatory, limitation on the exercise of federal jurisdiction.

52. See, e.g., Colorado River Water Conservation Dist. v. United States, 424 U.S. 800, 813 (1976); County of Allegheny v. Frank Mashuda Co., 360 U.S. 185, 188-89 (1959).

53. See note 8 supra. But see, e.g., Donohoe Constr. Co. v. Montgomery County Council, 567 F.2d 603 (4th Cir. 1977) (declining to abstain); Sixth Camden Corp. v. Township of Evesham, 420 F. Supp. 709 (D.N.J. 1976) (same).

54. In California, for example, the federal courts have abstained in nearly every case since 1970 challenging the state's innovative land use regulations. See, e.g., Santa Fe Land Improvement Co. v. City of Chula Vista, 596 F.2d 838 (9th Cir. 1979); Sederquist v. City of Tiburon, 590 F.2d 278 (9th Cir. 1978); Newport Invs., Inc. v. City of Laguna Beach, 564 F.2d 893 (9th Cir. 1977). But see Barbaccia v. County of Santa Clara, 451 F. Supp. 260, 264 (N.D. Cal. 1978) (declining to abstain because of "unique factual circumstances of this case"). 
structions of "uncertain state law" in applying Pullman abstention. A few courts have erroneously interpreted Younger to require exhaustion of state judicial remedies. ${ }^{56}$ Others have applied Burford to purely local regulatory programs without questioning whether the policy against interference with state administrative programs should apply with equal force to municipalities. ${ }^{.57}$

The frequency of federal court abstentions in land use cases, and the strained interpretations of traditional doctrine used to justify abstention, reflect judicial discomfort with the limits of traditional doctrine in the land use area. Abstention doctrine in the land use context could evolve in either of two directions. First, federal courts could continue

55. Judicial manipulation of the uncertain-state-law requirement in land use cases has assumed various forms. In Rancho Palos Verdes Corp. v. City of Laguna Beach, 547 F.2d 1092 (9th Cir. 1976), for example, the court held that federal equal protection and substantive due process challenges presupposed that plaintiffs held a "right" bestowed by state law-an uncertain question best resolved by the state courts. Id. at 1095. That reasoning was dubious. Although the scope of state-defined property rights may underlie federal procedural due process claims, see Board of Regents v. Roth, 408 U.S. 564, 577 (1972), equal protection or substantive due process challenges to land use regulations turn on whether the regulations are arbitrary or unreasonable, see, e.g., Steel Hill Dev., Inc. v. Town of Sanbornton, 469 F.2d 956, 960 (1st Cir. 1972). When a property owner challenges a regulation on due process or equal. protection grounds, therefore, no underlying state law right is at issue.

A second type of doctrinal manipulation occurred in Sederquist v. City of Tiburon, 590 F.2d 278 (9th Cir. 1978). In that case, the court suggested that state law was "doubtful" because the issue of whether a municipality had abused its discretion in refusing to issue a building permit turned "on the peculiar facts of each case." Id. at 282-83; cf. Santa Fe Land Improvement Co. v. City of Chula Vista, 596 F.2d 838, 841 (9th Cir. 1979) (whether city abused discretion by particular open-space zoning practices is question turning on facts of each case). But Pullman abstention was inappropriate in that case. Pullman abstention is used to avoid unnecessary interference with a valid state program by erroncous interpretation of an uncertain state legal issue. See p. 1140 supra. Federal and state courts are equally capable of applying settled state law to a difficult set of facts. Pullman abstention is not warranted in uncertain cases of this type.

Yet a third type of maneuver occurred in Newport Investments, Inc. v. City of Laguna Beach, 564 F.2d 893 (9th Cir. 1977), and Sederquist v. City of Tiburon, 590 F.2d 278 (9th Cir. 1978). Those courts reasoned that Pullman abstention was appropriate because insofar as plaintiff's takings claims rested on provisions of the California Constitution that are "mirror image[s]" of provisions in the United States Constitution, it was appropriate to afford the state an initial opportunity to decide the case under the state provisions. Such reasoning, however, would support Pullman abstention in all takings cases brought in federal court. Moreover, similar reasoning has been repudiated by the Supreme Court. See Wisconsin v. Constantineau, 400 U.S. 433, 437-39 (1971); Field, supra note 39, at 1099 n.108.

56. See Dells, Inc. v. Mundt, 400 F. Supp. 1293 (S.D.N.Y. 1975); Resources for Human Dev., Inc. v. Furber, 387 F. Supp. 11 (E.D. Pa. 1975); Salvati v. Dale, 364 F. Supp. 691 (W.D. Pa. 1973). The Supreme Court has never held that the Younger branch supports abstention absent a pending state suit. But cf. City of Columbus v. Leonard, 99 S. Ct. 3097 (1979) (mem.) (Rehnquist, J., dissenting) (proposing requirement of exhaustion of adequate state judicial remedies prior to commencing $\$ 1983$ action in federal court).

57. See, e.g., Kent Island Joint Venture v. Smith, 452 F. Supp. 455, 463 (D. Md. 1978); Stallworth v. City of Monroeville, 426 F. Supp. 236, 240 (S.D. Ala. 1976). 
to rely only on traditional abstention doctrine, but could declare that land use concerns deserve great weight in applying the conventional branches. Alternatively, federal courts could recognize land use concerns as independent bases for abstention even if traditional abstention requirements are not fully met. The latter policy is preferable in order to promote the values of federalism and to resolve land use disputes efficiently.

\section{The Justification for a Land Use Abstention Policy}

A number of public policies justify federal abstention in land use cases. Although some of these policies reflect traditional abstention concerns, their special and collective significance in the land use context justifies a distinct judicial policy for such cases.

\section{A. Policy Justifications}

Abstaining courts have not always made clear the bases for their decision. Many have simply declared that land use regulation is a "sensitive" area of state policyss or that it is a traditionally "local" activity. ${ }^{59}$ Such justifications are inadequate. ${ }^{60}$ Concededly, the sensitivity of state policy is a traditional reason for invoking Burford abstention, and judicial deference to local decisionmaking furthers federalist values. Yet the quality of sensitivity or the concept of localism cannot provide a principled rationale for abstention in land use cases: federal courts routinely decide local matters of the utmost sensitivity. ${ }^{01}$

58. E.g., Sederquist v. Gity of Tiburon, 590 F.2d 278, 281 (9th Cir. 1978); Webber v. Skoko, 432 F. Supp. 810, 813 (D. Or. 1977).

59. E.g., Hill v. City of El Paso, 437 F.2d 352, 357 (5th Cir. 1971); Kent Island Joint Venture v. Smith, 452 F. Supp. 455, 462 (D. Md. 1978).

60. At least one case also predicted that opening the federal courts to land use cases would add a significant number of cases to an already crowded federal docket. See Nationwide Amusements, Inc. v. Nattin, 325 F. Supp. 95, 93 (W.D. La.), rev'd on other grounds, 452 F.2d 651 (5th Cir. 1971). Avoiding court congestion is a questionable justification for abstention. Compare Wisconsin v. Constantineau, 400 U.S. 433, 443 (1971) (Burger, C.J., dissenting) (congestion of federal courts an appropriate rationale) and C. WRIGHT, Federal Courts $\S 52$, at 227-28 (3d ed. 1976) (same) with Thermtron Prods., Inc. v. Hermansdorfer, 423 U.S. 336, 344 (1976) (suit may not "be dismissed or referred to state courts" because federal court "considers itself too busy to try it"). Given the volume of land use litigation, see note 63 infra, if congestion were a permissible consideration in any class of cases, it certainly would be appropriate in the land use field.

61. If sensitivity were a sufficient justification for abstention, administration of local school systems would be a more appropriate field for abstention than is land use regulation. But federal courts clearly have not followed that reasoning. See, e.g., Columbus Bd. of Educ. v. Penick, 99 S. Ct. 2941 (1979) (ordering system-wide school desegregation); Keyes v. School Dist. No. 1, 413 U.S. 189 (1973) (same).

Some courts have used the term "local" to refer to the federalist values that would be 
Use of these terms may, however, reflect inchoate judicial concern for the values of federalism and efficiency. In that case, "sensitivity" and "local" might be regarded as proxies for four more-principled justifications for land use abstention: greater state court experience in deciding land use cases, superior state court knowledge of local conditions, a desire to avoid disruption of state land use programs, and promotion of state experimentation in land use policy.

\section{Greater Experience}

Several federal courts that have abstained in land use cases have noted that state courts possess greater experience in deciding land use cases than do federal courts. ${ }^{62}$ The greater volume of land use litigation in state courts ${ }^{63}$-a pattern likely to persist in spite of Lynch and Monell ${ }^{64}$ results in greater state court familiarity with land use problems in general and with the state's scheme of land use regulation in particular. As a result, state courts can resolve land use disputes in a more efficient and consistent manner.

\section{Familiarity with Local Conditions}

Abstaining courts also suggest that state courts are more familiar with local conditions than are federal courts. The smaller geographical jurisdiction of state, in contrast to federal, courts suggests that a state judge is likely to be more familiar with the parcel of land in dispute and

advanced by abstention. See, e.g., Kent Island Joint Venture v. Smith, 452 F. Supp. 455 (D. Md. 1978); Stallworth v. City of Monroeville, 426 F. Supp. 236 (S.D. Ala. 1976). One decision suggests that local land use disputes are simply trivial or routine, and for those reasons should be avoided by the federal courts whenever possible. See Hill v. City of El Paso, 437 F.2d 352, 356-57 (5th Cir. 1971). But under either rationale, abstention in all local disputes would frustrate the Civil Rights Act's objective of protecting against constitutional violations by local officials. See Developments-Federalism, supra note 49 , at 1153-54.

62. See, e.g., Kent Island Joint Venture v. Smith, 452 F. Supp. 455, 462 (D. Md. 1978); Stallworth v. City of Monroeville, 426 F. Supp. 236, 240 (S.D. Ala. 1976).

63. As of 1969 , just over 10,000 zoning cases had been decided in state courts. $N$. Williams, supra note 10 , at 555 . Given the increase in land use regulations, see F. Bosselman, D. Feurer, \& C. Siemon, The Permit Explosion: Coordination of the ProliferaTION (1976), and the general growth in litigation, the rate of accumulation of cases has probably increased in the $1970 \mathrm{~s}$. By contrast, as of January, 1980, approximately 150 land use cases had been decided in federal courts.

64. See pp. 1136-39 supra (discussing how Lynch and Monell have expanded federal court jurisdiction in zoning cases). Because section 1983 can be invoked only if a constitutional issue is present, challenges to land use regulations based on state common law, statutory, or constitutional grounds will generally continue to be brought in state courts. Morcover, the great majority of land use precedents have been set by state courts; a plaintiff may feel more confident in relying on those precedents if the case is brought in state court. Finally, in exclusionary zoning cases, for example, a plaintiff may be more likely to prevail under state law than under federal law. See note 12 supra. 
with its environs. ${ }^{65}$ Just resolution of substantive due process and takings challenges to land use regulations requires a court to consider physical characteristics of the site, social expectations regarding permissible land uses in the area, and the economic viability of alternative land uses. ${ }^{66}$ Insofar as a state judge is usually better able to assess those factors than is a federal judge, state court resolution of land use disputes is more likely to be correct. ${ }^{67}$

\section{Avoidance of Disruption}

A third justification for federal deference is that land use regulation often involves an extensive and elaborate administrative program in which both the state and numerous local governments participate. ${ }^{68}$ Federal court challenges to such programs frequently require decision of uncertain state legal questions or application of settled state law to complex, uncertain facts. ${ }^{69}$ The likely results are conflicting interpreta-

65. In California, for example, the federal district court is divided into four judicial districts; by contrast, the state superior court-the court of general jurisdiction in California-sits in each of the state's 58 counties. The AMERICAN BENch 170-75, 185 (M. Reincke ed. 1979). New Jersey has only one federal district, but the state superior courts sit in each of the state's 21 counties. See N.J. Const. art. 6, $\$ 3$. Florida is divided into three federal districts, but 20 state circuit court districts. The American Bench, supra, at 412, 414-16.

The requirement in many states that a judge reside in the district in which he serves, e.g., Cal. Gov'T Code $\S 69502$ (West 1976); N.J. ConsT. art. 6, $\S 3$, is also likely to result in state court judges having a greater familiarity with local conditions than federal judges will have.

66. Cf. Village of Euclid v. Ambler Realty Co., 272 U.S. 365, 387 (1926) (legitimacy of zoning plan "varies with circumstances and conditions. A regulatory zoning ordinance, which would be clearly valid as applied to the great cities, might be clearly invalid as applied to rural communities.") For example, a minimum lot size for residential use of four acres may be unreasonable in one community, see, e.g., National Land $\$$ Inv. Co. v. Kohn, 419 Pa. 504, 215 A.2d 597 (1965), but a minimum lot size of 43 acres may be permissible under different conditions, see, e.g., Adirondack Park Agency v. Ton-Da-Lay Assocs., 61 A.D.2d 107, 401 N.Y.S.2d 903, appeal dismissed, 45 N.Y.2d 834, 381 N.E.2d 612, 409 N.Y.S.2d 214 (1978). Because a state judge will be more familiar with the local environs, he is likely to be more sensitive than a federal judge to these local factors, and therefore more likely to apply the Euclid standards correctly.

67. Federal jurors are drawn from wider geographical areas than are state jurors. United Steelworkers v. R.H. Bouligny, Inc., 382 U.S. 145, 150 (1965); see 28 U.S.C. $\$ 1861$ (1976) (petit juries selected from community in the judicial district or division). State jurors, then, like state judges, are probably more sensitive to local conditions and hence better equipped to apply Euclid standards correctly.

68. In many states, adoption of a comprehensive plan consistent with state standards is a precondition for municipal land use regulations. See, e.g., CAL. Gov'T CodE $\$ 65302.4$ (West 1980); OR. Rev. Stat. $\$ 197.175$ (1977). As of 1975, sixteen states had adopted one or more state-level land use controls. See N. Willisms, supra note 10, $\$ 160.01$, at 389 .

69. See, e.g., Santa Fe Land Improvement Co. v. City of Chula Vista, 596 F.2d 838, 841 (9th Cir. 1979); Rancho Palos Verdes Corp. v. City of Laguna Beach, 547 F.2d 1092, 1095 (9th Cir. 1976). The Supreme Court has held that federal courts should decide state law questions first if doing so might avoid a constitutional issue. Siler v. Louisville \& Nashville R.R., 213 U.S. 175, 193 (1909). A federal court may also be required to interpret state law in order to identify which constitutional issues are present. See Field, supra note 39, at 1111. 
tions of state land use regulations by federal and state courts, ${ }^{70}$ interference with efficient resolution of land use disputes, ${ }^{71}$ and disruption of state efforts to establish a coherent land use policy. ${ }^{72}$ The traditional objective of both the Burford and Pullman doctrines-avoiding interference with state programs-is therefore furthered by abstention in most land use cases.73

\section{Promotion of Experimentation}

Finally, because the permissible and appropriate scope of public regulation of private land use has not been resolved, ${ }^{74}$ land use regulation is a proper subject for state experimentation free from federal interference. A few federal courts have recognized explicitly that federal adjudication of land use disputes would tend to create a uniform, national land use law, interfering with state initiatives in land use policy. ${ }^{75}$ By contrast, a land use abstention policy would encourage state innovation.

\section{B. The Need for a Distinct Land Use Abstention Policy}

The justifications for land use abstention indicate that an abstention policy would foster important federalist values and would facilitate efficient resolution of land use cases. ${ }^{76}$ Federal courts should therefore

70. See Santa Fe Land Improvement Co. v. City of Chula Vista, 7I F.R.D. 573, 576 (S.D. Cal. 1976), aff'd, 596 F.2d 838 (9th Cir. 1979) (noting state courts had not yet interpreted recent California land use legislation). A federal court's construction of state law might be erroneous in the sense that the highest state court might later contradict that holding. The error may not - be corrected until the same issue is presented to the state supreme court in a subsequent case. See Field, supra note 39, at 1095, 1111.

71. E.g., Rancho Palos Verdes Corp. v. City of Laguna Beach, 547 F.2d 1092, 1095 (9th Cir. 1976); Santa Fe Land Improvement Co. v. City of Chula Vista, 71 F.R.D. 573, 576 (S.D. Cal. 1976), aff'd, 596 F.2d 838 (9th Cir. 1979).

72. E.g., Fralin \& Waldron, Inc. v. City of Martinsville, 493 F.2d 481, 483 (4th Cir. 1974); Santa Fe Land Improvement Co. v. City of Chula Vista, 71 F.R.D. 573, 576 (S.D. Cal. 1976), aff'd, 596 F.2d 838 (9th Cir. 1979).

73. See p. 1141 supra (discussing Burford). Pullman abstention reduces the risk of improper interference with a valid state program because the federal court might erroneously invalidate the state program on state law grounds. See Field, supra note 39, at 1078.

74. See, e.g., B. Ackerman, Private Property and the Constitution 8 (1977) (takings law in state of confusion).

75. E.g., Rancho Palos Verdes Corp. v. City of Laguna Beach, 547 F.2d 1092, 1095 (9th Cir. 1976); Kent Island Joint Venture v. Smith, 452 F. Supp. 455, 462 (D. Md. 1978).

76. The more efficient resolution of land use disputes that will result from concentration of land use cases in state courts must be weighed against the sometimes "considerable delay and expense," Field, supra note 39 , at 1085 , caused by abstention. The costs of abstention can be minimized if the scope of the abstention policy is clearly defined, see pp. 1149-54 infra, and if a federal court dismisses the case, rather than retaining jurisdiction after abstaining, see note 42 supra (dismissal required in Burford abstention). 
abstain in land use cases even if traditional abstention requirements cannot be fully satisfied.

Although the policies supporting land use abstention are related to traditional abstention concerns, the formal requirements for invoking the three types of abstention would not be satisfied in most land use cases. In only a minority of land use cases would Pullman abstention be justified by the presence of an uncertain state law claim that would modify a federal constitutional issue. Younger abstention could only be considered in the few cases in which concurrent, state-initiated proceedings were pending.

The Burford doctrine, unlike the other two branches, embodies many of the concerns that justify a land use abstention policy. But Burford abstention is distinguishable from the proposed land use policy in several respects. ${ }^{77}$ In Burford, the Court affirmed dismissal of a federal suit to enjoin execution of a state administrative grant of an oil-drilling permit. ${ }^{78}$ The Court reasoned that oil drilling involved "basic problems of Texas policy,"79 that a complex state regulatory scheme had been established to resolve those problems, ${ }^{80}$ and that the state had concentrated judicial review of administrative orders in one set of state courts. ${ }^{81}$ In contrast to the regulatory scheme challenged in Burford, state land use programs generally do not provide for review of regulatory decisions by a single court or set of courts. ${ }^{82}$ Moreover, whereas the proposed land use abstention policy would justify abstention in some challenges to local regulations, Burford abstention has generally been limited to state-level regulatory programs. ${ }^{83}$

77. Only a few courts have explicitly relied on Burford to justify abstention in land use cases. Compare Kent Island Joint Venture v. Smith, 452 F. Supp. 455, 464 (D. Md. 1978) (invoking Burford abstention) and Sea Ranch Ass'n v. California Coastal Zone Conservation Comm'n, 396 F. Supp. 533 (N.D. Cal. 1975), aff'd, 537 F.2d 1058 (9th Cir. 1976) (same) with Santa Fe Land Improvement Co. v. City' of Chula Vista, 596 F.2d 838, 841-42 (9th Cir. 1979) (declining to invoke Burford) and Rancho Palos Verdes Corp. v. City of Laguna Beach, 547 F.2d 1092, 1096 (9th Cir. 1976) (sarae).

78. 319 U.S. at 334 .

79. Id. at 332 .

80. Id. at $320-21$.

81. Id. at 325-26. The Court also relied on the presence of a unified system of judicial review in Alabama Pub. Serv. Comm'n v. Southern Ry., 341 U.S. 341, 348-49 (1951), another leading case in the Burford line.

82. E.g., CoNN. GEN. STAT. $\$ \S 8-8,8-9$ (1979) (appeal from decision of zoning or planning board is to "the superior court for the judicial district in which such municipality is located"); N.Y. VILLAGE LAW $\$ 7-712$ (McKinney 1973) (appeal to supreme court). But see VT. STAT. ANN. tit. 10, $\$ 6089$ (1979) (appeal from state environmental board is to state supreme court).

83. Supreme Court decisions invoking Burford have involved state, not local, regulatory policies or activities. See, e.g., Alabama Pub. Serv. Comm'n v. Southern Ry., 341 U.S. 341 (1951) (state public service commission); Stainback v. Mo Hock Ke Lok Po, 336 U.S. 368 
Although the Supreme Court has not discussed the possibility of a general land use abstention policy, it did suggest in Louisiana Power \& Light Co. v. City of Thibodaux ${ }^{84}$ that a liberal abstention rule might be appropriate in eminent domain cases, a small set of land use cases subsumed by the policy proposed here. In other situations, it has permitted the expansion of abstention doctrine when adequate policy reasons for recognizing a new branch existed. ${ }^{85}$ The expanding volume of federal land use litigation now justifies creation of a distinct land use abstention category.

\section{The Limits of Land Use Abstention Policy}

Although abstention in land use cases would advance federalist and efficiency values, the proposed policy would in part displace federal courts as primary guarantors of constitutional norms. The risk of less effective protection of constitutional rights by state courts suggests that federal courts should abstain only in those cases in which the policy's underlying values would be most frequently advanced, while preserving a federal forum for those cases in which federal protection of constitutional rights is most critical.

\section{A. General Obligation to Hear Federal Claims}

The "virtually unflagging obligation"se of federal courts to decide cases properly before them precludes a categorical rule against federal adjudication of land use cases-particularly because most federal land

(1949) (state legislation regarding teaching of foreign languages). But cf. Allegheny County v. Frank Mashuda Co., 360 U.S. 185 (1959) (challenge to county eminent domain proceedings not barred by Burford).

84. 360 U.S. 25 (1959). The current scope and vitality of Thibodaux abstention is uncertain. In County of Allegheny v. Frank Mashuda Co., 360 U.S. 185 (1959), decided the same day as Thibodaux, the Court reversed the dismissal of a challenge to state eminent domain proceedings, stating that eminent domain did not represent a special category in abstention doctrine. Id. at 191-92; see Field, supra note 39, at 1148-53 (discussing Thibodaux abstention). These conflicting authorities have led to inconsistent treatment of challenges to eminent domain proceedings. Compare Ahrensfeld v. Stephens, 528 F.2d 193 (7th Cir. 1975) (abstaining) with Joiner v. City of Dallas, 380 F. Supp. 754 (N.D. Tex. 1974) (not abstaining). Nevertheless, Thibodaux demonstrates both the Court's sensitivity to the special character of land use cases and the capacity of abstention doctrine to evolve to meet new judicial concerns.

85. The three traditional branches of abstention doctrine emerged over a period of 30 years. The Younger branch in particular has been expanded greatly in recent years. See note 46 supra. The possibility of a fourth abstention category was raised in Colorado River Water Conservation Dist. v. United States, 424 U.S. 800, 818 (1976) (when traditional abstention requirements are not met, federal suit may still be dismissed "due to the presence of a concurrent state proceeding for reasons of wise judicial administration").

86. Colorado River Water Conservation Dist. v. United States, 424 U.S. 800, 817 (1976). 
use cases will arise as section 1983 actions. ${ }^{87}$ The Fourteenth Amendment and section 1983 prohibit states from depriving a citizen of his constitutional rights. ${ }^{88}$ These constitutional and statutory mandates bar total federal judicial abdication even in a field so narrowly defined as land use.

\section{B. Guidelines for Abstention}

Resolution of the conflict between judicial deference to the states and enforcement of constitutional norms requires qualification of the general land use abstention policy proposed here. Because a court must rule on an abstention motion prior to trial on the merits, ${ }^{80}$ a federal judge cannot be certain whether a constitutional violation has occurred, although he can accurately assess the efficiency and federalism concerns at stake. Taking that uncertainty into account, it is possible to identify several guidelines for abstention that would promote federalist values and efficient resolution of land use disputes, while preserving the constitutional rights protected by section 1983 .

\section{Fundamental Versus Nonfundamental Rights}

First, the abstention policy should be disregarded when a plaintiff contends that a land use regulation infringes fundamental constitutional rights. Such rights would include fundamental interests protected by the due process ${ }^{90}$ and equal protection clauses, ${ }^{01}$ the right to be free of discrimination as a member of a suspect group, ${ }^{92}$ and the

87. Some judges and commentators have suggested that abstention is inappropriate in civil rights cases. E.g., Harrison v. NAACP, 360 U.S. 167, 180-81 (1959) (Douglas, J., dissenting); Wechsler, Federal Jurisdiction and the Revision of the Judicial Code, 13 LAw \& Contemp. Prob. 216, 230 (Winter 1948). The Court, however, has not adopted a rule against abstention in civil rights cases. See Askew v. Hargrave, 401 U.S. 476 (1971) (per curiam); Harrison v. NAACP, 360 U.S. 167 (1959). Given the breadth of the section 1983 action after Lynch v. Household Fin. Corp., 405 U.S. 538 (1972); see pp. 1136-37 supra, such a rule would create an enormous exception to the abstention doctrine.

88. Monroe v. Pape, 365 U.S. 167 (1961); see Developments-Federalism, supra note 49, at $1167-75$.

89. See England v. Louisiana State Bd. of Medical Examiners, 375 U.S. 411, 416 (1964). But cf. Field, supra note 39, at 1102-03, 1108-11 (proposing that federal courts prejudge merits of abstention cases in order to identify policies that would be served by abstention).

90. See, e.g., Moore v. City of East Cleveland, 431 U.S. 494 (1977) (family relationships protected from municipal interference).

91. See, e.g., Construction Indus. Ass'n v. City of Petaluma, 375 F. Supp. 574 (N.D. Cal. 1974), rev'd on other grounds, 522 F.2d 897 (9th Cir. 1975), cert. denied, 424 U.S. 934 (1976) (right to travel).

92. See, e.g., Fralin \& Waldron, Inc. v. County of Henrico, 474 F. Supp. 1315 (E.D. Va. 1979) (motion to abstain denied in suit alleging racially discriminatory administration of land use regulations). 
right of free speech. ${ }^{93}$ The importance of these constitutional rights, ${ }^{94}$ and the fact that federal courts are generally more effective than state courts in protecting them, ${ }^{95}$ outweigh the federalism and efficiency concerns supporting abstention. In land use cases involving alleged infringements of fundamental rights, therefore, the normal presumption that abstention is the "exception, not the rule" should govern. Although the distinction between fundamental and nonfundamental rights would significantly restrict the scope of the proposed abstention policy, it would still permit federal courts to direct a majority of land use cases to the state courts: cases involving takings, rational-relation due process, and procedural due process claims.

\section{State Versus Local Policies}

Second, abstention is more appropriate in cases involving state rather than purely local land use policies. ${ }^{90} \mathrm{~A}$ lesser degree of deference toward local policies is appropriate because local governments are not restrained by the plurality of interests that compete at the state level and

93. See, e.g., Tovar v. Billmeyer, 609 F.2d 1291 (9th Cir. 1979) (decision to abstain reversed in suit claiming abridgment of First Amendment).

94. Some commentators regard the need for federal protection of fundamental rights as requiring a per se rule against abstention when such rights are at issue. See, e.g., American L.aw Instirute, Study of the Division of Jurisdiction Between State and Federal CourTs $\$ 1371(\mathrm{~g})$, at 50 (1969) (abstention not appropriate in cases involving denial of vote or discrimination based on race, creed, color, or national origin); $c f$. Field, supra note 39, at 1129-31 (presence of fundamental rights claims, including violations of First Amendment and racial discrimination, weigh against abstention). Cases involving fundamental constitutional rights, however, may also present "sensitive" constitutional questions, see p. 1140 supra; the presence of such questions militates in favor of abstention, see Field, supra note 39 , at 1131 n.160.

95. Professor Neuborne argues, first, that federal courts possess greater technical legal competence and are therefore more assertive in enforcing legal rights; second, that the federal courts" "psychological set" makes it more likely that a constitutional claim will succeed in federal court than in state court; and, third, that the federal courts' greater insulation from the political process renders them more prone to counter the will of the majority. Neuborne, supra note 34 , at 1120-28; cf. N. DoRsen, P. BENDER, \& B. NeubORNE, supra note 34 , at $1293-94$ (federal courts are primary guarantors of constitutional freedoms); Mishkin, The Federal "Question" in the District Courts, 53 Colum. L. REv. 157, 158-59 (1953) (federal courts enforce national rights established by Supreme Court rulings more consistently than state courts). The Supreme Court, however, has repeatedly reaffirmed that state courts are presumptively as effective as federal courts in protecting constitutional rights. See note 34 supra (citing cases).

96. A few land use cases have recognized this distinction. Compare Rancho Palos Verdes Corp. v. City of Laguna Beach, 547 F.2d 1092, 1094 \& $n .5$ (9th Cir. 1976) (abstention warranted because California has adopted open space policy and municipalities are required to include open space element in master plans) with Lerner v. Town of Islip, 272 F. Supp. 664, 667-68 (E.D.N.Y. 1967) (when "there is no single source of state judicial or administrative control," cannot be said that "redress to the federal courts by a property owner threatens to undermine the state's land use program"). 
can more easily be manipulated to further narrow, parochial interests. ${ }^{97}$ Municipal land use decisions are likely, moreover, to be less wellinformed than state-level decisions. ${ }^{98}$ Constitutional rights are therefore more likely to be violated when a municipality, rather than a state, regulates land use. ${ }^{99}$ Relatively infrequent application of the abstention policy in challenges to purely local land use decisions is thus necessary to preserve access to a federal forum for individuals with legitimate constitutional claims.

Several additional factors militate in favor of more frequent abstention when state-authorized land use policies are challenged. First, although federal judicial deference to either states or local governments promotes federalist values, the Supreme Court has explicitly recognized that state sovereignty deserves greater respect. ${ }^{100}$ Second, federal intervention would have a more disruptive effect on a statewide land use program than it would on a purely local one. ${ }^{101}$ Finally, deference to state land use decisions would reinforce the national policy of en-

97. For an extreme example of monopolization of local government powers, see Whitworth v. Perkins, 559 F.2d 378 (5th Cir. 1977), vacated sub nom. City of Impact v. Whitworth, 435 U.S. 992 (1978), opinion reinstated per curiam sub nom. Whitworth v. Perkins, 576 F.2d 696 (5th Cir. 1978), cert. denied, 440 U.S. 911 (1979) (conspiracy exists among government officials, developer of town, and liquor retailers to incorporate "wet" town within "dry" county and to prevent other town residents from selling alcoholic beverages by excluding liquor establishments from noncommercial zones).

98. Municipalities generally lack the technical legal and planning assistance available to state agencics. See R. BABcock, The Zoning Game 38-40 (1966); Developments-Zoning, supra note 28 , at 1591 . These generalizations may not apply, however, to those urban communities with populations over 100,000; those communities, however, constitute only 2\% of all cities. See U.S. Dep't of Commerce, Statistical Abstract of the United States 23 (1979) (Chart No. 22). Many of these communities have as structured a land use program as some states. See, e.g., New York City Charter \& AdM. Code $\$ \$ 191-202$ (1976 \& Supp. 1979). Courts should consider whether certain urban regulatory programs carry the same indicia of political accountability and technical expertise as state programs and therefore should be accorded the same degree of federal deference.

99. It is a tenet of American political thought that the risk of abuse of governmental powers increases as the size of the political unit decreases. See, e.g., The Federalist No. 10 (J. Madison); cf. B. ACKerman, supra note 74, at $210 \mathrm{n.31}$ (local land use regulatory authorities entitled to degree of judicial deference intermediate between that assigned to "self-aggrandizing" bureaucracies and "the central legislative processes of the state or nation").

100. See, e.g., City of Lafayette v. Louisiana Power \& Light Co., 435 U.S. 389, 412 (1978) (cities not sovereign); Reynolds v. Sims, 377 U.S. 533, 575 (1964) (counties and cities are not "sovereign entities"; they are "subordinate governmental instrumentalities created by the State to assist in the carrying out of state governmental functions"). The Constitution distinguishes between states and subordinate entities in a variety of ways. For example, the Eleventh Amendment does not protect municipalities from suit in federal court. Lincoln County v. Luning, 133 U.S. 529 (1890). The Supreme Court's original jurisdiction extends to cases "in which a State shall be a party." U.S. CoNst. art. $3, \S 2$, cl. 2.

101. See p. 1146-47 supra. 
couraging states to assume greater responsibility for land use regulation. ${ }^{102}$

\section{Systemic Versus Individual Challenges}

As a third limitation on the proposed policy, abstention should be invoked more readily in a challenge to a broad regulatory scheme than in a claim of unlawful government action against an individual landowner. ${ }^{103}$ Federal invalidation of a comprehensive regulatory program, or of a decision issued pursuant to such a program, is more disruptive of efforts to develop a coherent land use policy than is invalidation of a particular decision directed against an individual landowner. ${ }^{104}$ Federal court abstention in the former case clearly would advance federalism and efficiency but would be of less importance in the latter case. The political process, moreover, provides less protection against unfair treatment of an individual than of numerous landowners affected by a general regulation..$^{105}$ The ostensible purpose of section

102. See, e.g., 16 U.S.C. $\$ 1451(\mathrm{~h})$ (1976) ("The key to more effective protection and use of the land and water resources of the coastal zone is to encourage the states to exercise their full authority over the land and waters in the coastal zone"); 40 U.S.C. $\$ 461$ (1976) (authorizing federal funds for comprehensive state planning). Most commentators agree that purely local land use regulation fails to reflect the social and economic interrelationships of the municipality, the surrounding region, and the state. See, e.g., R. BABcock, supra note 98, at 145-50, 159-66; U.S. Council on ENvironmental Quality, The Quict Revolution IN LAND Use Controls 2-3 (1971); Developments-Zoning, supra note 28 , at $1590-92$.

103. Cases denying, as well as granting, abstention motions have relied on this distinction. Compare Donohoe Constr. Co. v. Montgomery County Council, 567 F.2d 603, 607 n.12 (4th Cir. 1977) ("Rather than a broadside attack on an entire statutory scheme, this suit alleges merely an isolated abuse of state power.") and Weiss v. Willow Tree Civic Ass'n, 467 F. Supp. 803, 808 n.10 (S.D.N.Y. 1979) (same) with Kent Island Joint Venture v. Smith, 452 F. Supp. 455,464 (D. Md. 1978) ("Unlike the present case, Donahoe [sic] did not concern the reasonableness of a land use classification made pursuant to a comprehensive regulatory scheme.") and Forest Hills Util. Co. v. City of Heath, 539 F.2d 592 (6th Cir. 1976) (same).

Although the dividing line between these two classes of cases will be difficult to draw, most cases will be readily identifiable as belonging to one class or the other. For example, it is clear that a court should abstain when a landowner attacks a general zoning classification, see, e.g., Stallworth v. City of Monroeville, 426 F. Supp. 236 (S.D. Ala. 1976), but should not abstain from deciding whether a municipality downzoned (i.e., reduced the permitted density of development) a particular parcel in order to reduce its cost to the municipality in later eminent domain proccedings, see, e.g., Donohoe Constr. Co. v. Montgomery County Council, 567 F.2d 603 (4th Cir. 1977).

104. Professor Field argues that Pullman abstention should not distinguish between challenges to broad regulatory programs and challenges to an official's authorization for particular conduct. Field, supra note 39, at 1123-25. Although Field is correct that federal interference in either case will limit the scope of permissible government activities, $i d$, the interference is likely to be less extensive when a particular official act is challenged because the conduct at issue is less likely to be repeated.

105. Cf. United States v. Carolene Prods. Co., 304 U.S. 144, 152 n.4 (1938); B. AcKerman, supra note 74, at 52 (court should be especially vigilant in reviewing governmental decisions imposing burden of collective enterprise on small set of property owners). 
1983 was to prevent state officials from singling out individuals for abuse, not to authorize federal judicial supervision of state regulatory programs. ${ }^{106}$

\section{Conclusion}

The abstention doctrine is an appropriate judicial device for directing the majority of land use litigants into state courts. A land use abstention policy would further important federalist values and would facilitate efficient resolution of land use disputes. But the importance of fundamental constitutional rights, and the greater vigilance of federal courts in protecting those rights, should preclude abstention when infringement of such rights is asserted. Moreover, courts should carefully weigh the competing values at stake in deciding whether or not to abstain when the challenge is to purely local regulations, or when the claim is that regulatory authorities have singled out an individual for unfair treatment.

106. See Developments-Federalism, supra note 49, at 1153.54 (Civil Rights Act of 1871 enacted principally to remedy complicity of state and local officials in terrorism against black leaders and Union sympathizers). 